\title{
The Use of Team Games Tournament Method for Reading Javanese Lettered Text in Vocational High School
}

\author{
A Septianawati ${ }^{1}$, B Setiawan ${ }^{2}, \mathrm{M}$ Rohmadi $^{3}, \mathrm{~K} \mathrm{Saddhono}^{4}$

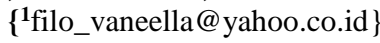 \\ 1,2,3,4 Universitas Sebelas Maret Surakarta, Indonesia
}

\begin{abstract}
This study aims to determine whether the application of the Team Games Tournament (TGT) method with sentence puzzle media is able to improve the passive situation of students in reading Javanese texts in Javanese learning. The type of research used is classroom action research. This study consisted of two cycles. Each cycle consists of four stages, namely planning, action, observation, and reflection. The research subjects were students from one class in a vocational high school in East Java, Indonesia. The results showed that the application of the Team Games Tournament (TGT) method had several positive effects in improving students' passive situations in reading Javanese text in Javanese language learning.
\end{abstract}

Keywords: team games tournament, reading comprehension, Javanese lettered text

\section{INTRODUCTION}

Language learning is complex learning. Learning a language is very important because language grows and develops with the wearer community [1]. In language learning, students are required to have four language skills, namely listening, speaking, reading and writing skills. Language skills affect one another. The main function of the language is as a means and tool of communication [2]. Talking about learning cannot be separated from the learning variable itself. Learning variables include learning conditions, learning methods, and learning outcomes [3]. The ability of the teacher to use the right method in learning greatly affects the learning outcomes. This is because one professional teacher indicator is able to prepare the learning component as well as possible which includes learning objectives, learning materials, learning methods, learning media, and learning evaluation [4]. [5] applied cooperative learning to increase students' enthusiasm and active participation in reading activities in English classes. The application of cooperative learning used by [5] is able to increase enthusiasm and student participation in reading activities.

[6] examined the impact of playing a game on the performance and attitudes of class VIII students on mathematics lesson. After three weeks of intervention, the application of the Team Games Tournament (TGT) for the experimental group students had achieved significant learning outcomes compared to the control group students. The TGT experimental group also showed different attitudes toward certain positive limits to mathematics. [7] examined the effect of the Team Games Tournament (TGT) learning model using teaching aids in terms of spatial intelligence on mathematics learning achievement. This quasi-experimental research was 
conducted on mathematics learning in a three-dimensional material. The results showed that mathematics learning achievement was better when using $3 \mathrm{D}$ teaching aids than $2 \mathrm{D}$ props.

Furthermore, [8] examined the influence of the application of the Team Games Tournament (TGT) method by playing dice on science learning outcomes. The results showed significant differences between learning outcomes through the Team Games Tournament (TGT) method and learning outcomes through discussion methods. the results of the average posttest value after being applied the Team Games Tournament (TGT) method was 72.1. The average value of this value increases compared to the average value of the pretest before applying the Team Games Tournament (TGT) method, which is 57.

The application of the Team Games Tournament (TGT) method can not only be applied to language learning but can also be applied to science learning. This depends on the creativity of the teacher to use the right method in delivering the material. The teacher as a teacher is a teacher who is able to create the best learning situation [9]. In this study, the application of the Team Games Tournament (TGT) method was used to increase the activity of students in Javanese language learning in reading Javanese letters.

Preliminary observations showed that students who actively asked were $53.12 \%$, active students answered $46.87 \%$, students take notes without being instructed $46.87 \%$, students who attend learning in an orderly manner $43.75 \%$, and students did not get sleepy $43.75 \%$. Some students pay attention to the teacher's explanation while others feel bored and noisy themselves. The attitude of these students influenced their interest in participating in learning to read Javanese lettered texts. Therefore, researchers further examine the low attitudes of students in learning to read Javanese lettered texts.

Teachers and researchers seek to improve the quality of the learning process which includes student performance and teacher performance. The use of the Team Game Tournament (TGT) method with sentence puzzle media can be used as an alternative to learning to read Javanese lettered texts. The use of the Team Game Tournament (TGT) method stimulates the enthusiasm and power of student competition. Competition can make students keep trying to correct mistakes and shortcomings to get the best results. The use of the Team Game Tournament (TGT) method also stimulates students to work with friends in a team. Students must work together with their team so that they are able to complete the tasks given by the teacher correctly and quickly. This shows that the use of the Team Game Tournament (TGT) method can foster social attitudes namely cooperation between students in the team.

The application of the Team Game Tournament (TGT) method requires an educational game that supports it. The type of educational games is also easy to create and use [10]. Educational games are needed to help implement the Team Game Tournament (TGT) method and make students feel comfortable, happy, and enthusiastic during learning. The use of educational games can make students play while learning. Learning experiences gained through playing can make students understand the subject matter easily compared to the lecture method. Educational games that are used can vary depending on the subject matter to be taught. Seeing some positive things, the Team Game Tournament (TGT) method with sentence puzzle media can be used as a teacher's consideration in Javanese language learning activities.

Based on the description above, the problem to be examined is whether the use of the Team Games Tournament (TGT) method can improve the passive situation of students in learning to read Javanese lettered texts. 


\section{RESEARCH METHOD}

This classroom action research was conducted at Kasiman State Vocational School located at Jalan Wonosari, Sambeng - Kasiman, Bojonegoro Regency, East Java. The subjects of the study were Javanese language teachers and class X TKR 1 . The time of implementation in the even semester of the academic year 2016/2017. The research subjects were 32 students with all male students. This research was conducted in two cycles. Each cycle consists of four stages, namely planning, action, observation, and reflection. Data collection techniques in research are carried out by observation, interviews, document analysis, and tests. Observations applied in the form of passive observations, meaning that observers are not directly involved in the implementation of learning. Observations were made on teachers when carrying out teaching and learning activities in the classroom as well as on student performance during the teaching and learning process took place. Interviews were carried out after observations in both classroom learning and document studies and before action was taken. Document analysis is carried out on various documents such as curriculum, Learning Implementation Plan (RPP), books or subject matter and a list of values given by the teacher. The test is conducted to determine the measure of success achieved by students after the implementation of the action in learning. Data analysis carried out is critical analysis and Fixed comparison analysis. Critical analysis is used to analyze data from observations and interviews. Fixed comparison analysis is used in comparing pre-cycle with the cycle I and cycle I with cycle II.

\section{RESULT AND DISCUSSION}

The results of the interview with the teacher indicate that the method used by the teacher during the process of learning to read Javanese lettered texts takes place is the lecture method and the assignment of assignments. The role of teachers is very dominating during the learning process, causing students to be bored and less interested in learning materials. The teacher also has not used learning media that attract students to take part in learning. Based on this, it can be concluded that the problems experienced by the teacher during the process of learning to read Javanese lettered texts are less varied methods and learning media used by the teacher, causing the ability of students to read Javanese lettered texts is still low.

The attitude of students shows an attitude that is less active during learning to read Javanese lettered texts in progress. Based on observations, there were $53.12 \%$ of students who actively asked, active students answered $46.87 \%$, students take notes without being instructed $46.87 \%$, students who attend learning in an orderly manner $43.75 \%$, and students did not get sleepy $43.75 \%$. Some students pay attention to the teacher's explanation while others feel bored and noisy themselves. The attitude of these students influenced their interest in participating in learning to read Javanese letters so that the ability to read Javanese lettered texts was still low. 


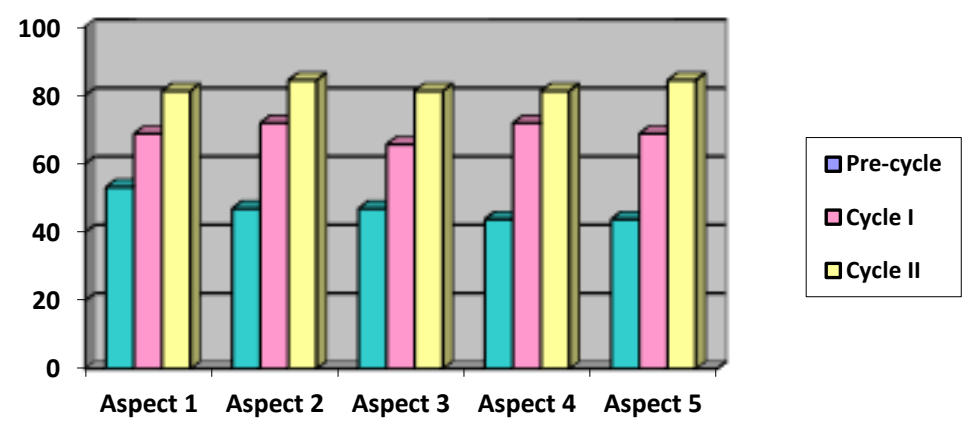

Figure 1. Graph Comparison of Student Performance in Pre-cycle, Cycle I, and Cycle II

In the second cycle there was an increase in student activity compared to pre-cycle and cycle I. Active students asked as much as $81.25 \%$ or increased by $28.13 \%$ from pre-cycle. Students who answered questions from teachers were $84.37 \%$ or increased by $37.5 \%$ from pre-cycle. A total of $81.25 \%$ of students take notes without being instructed or increased by $34.38 \%$. Students who attend learning in an orderly manner as much as $81.25 \%$ or an increase of $37.5 \%$. Students who are not sleepy during learning are $84.37 \%$ or an increase of $40.62 \%$.

Before action or pre-cycle, student activity is still low in learning to read Javanese lettered texts. This student activity is characterized by several factors, namely: (1) actively asking questions, (2) answering questions from the teacher, (3) taking notes without prompting, (4) orderly taking lessons, and (5) not drowsy during the lesson. Students who actively asked were $53.12 \%$. Students who answered questions from teachers were only $46.87 \%$. Students who students take notes without being instructed $46.87 \%$. A total of $43.75 \%$ of students who attend learning in an orderly. Students who are not sleepy during learning are $43.75 \%$.

After the Team Game Tournament (TGT) method was applied with sentence puzzle media in students of class X TKR 1 State Vocational School Kasiman, the quality of the process of learning to read Javanese lettered texts increased significantly. This can be seen from the activity of students which increases compared to pre-cycle. Active students ask as much as $81.25 \%$ or experience an increase of $28.13 \%$ from prasiklus. Students who answered questions from teachers were $84.37 \%$ or increased by $37.5 \%$ from pre-cycle. A total of $81.25 \%$ of students take notes without being instructed or increased by $34.38 \%$. students who attend learning in an orderly manner as much as $81.25 \%$ or an increase of $37.5 \%$. Students who are not sleepy during learning are $84.37 \%$ or an increase of $40.62 \%$.

Increasing student activity in the learning process can be seen from changes in student enthusiasm during the learning process. One of the factors that influence student enthusiasm is the giving of motivation by the teacher. The teacher always motivates and guides students when they experience difficulties in understanding Javanese text. In addition, reflection on learning outcomes makes students try to correct mistakes made in the previous cycle.

In the opinion of students, learning using the Team Game Tournament (TGT) method and the use of sentence puzzle media can help them understand Javanese text. The spirit of competition encourages students to be more motivated to take part in learning to read Javanese lettered texts. Interest and motivation largely determine the success of student learning. The application of the Team Game Tournament (TGT) method can foster internal motivation within 
students so that students are more interested in learning to read Javanese lettered texts. Increased student activity is also due to the success of the teacher as a motivator. Giving motivation done by the teacher in the form of praise and applause is a source of extrinsic motivation for students so that they are more passionate and enthusiastic to take part in learning.

[6] examined the impact of playing a game on the performance and attitudes of class VIII students on mathematics lesson. After three weeks of intervention, the application of the Team Games Tournament (TGT) for the experimental group students had achieved significant learning outcomes compared to the control group students. The TGT experimental group also showed different attitudes toward certain positive limits to mathematics. [7] examined the effect of the Team Games Tournament (TGT) learning model using teaching aids in terms of spatial intelligence on mathematics learning achievement. This quasi-experimental research was conducted on mathematics learning in a three-dimensional material. The results showed that mathematics learning achievement was better when using $3 \mathrm{D}$ teaching aids than $2 \mathrm{D}$ props.

Furthermore, [8] examined the influence of the application of the Team Games Tournament (TGT) method by playing dice on science learning outcomes. The results showed significant differences between learning outcomes through the Team Games Tournament (TGT) method and learning outcomes through discussion methods. the results of the average posttest value after being applied the Team Games Tournament (TGT) method was 72.1. The average value of this value increases compared to the average value of the pretest before applying the Team Games Tournament (TGT) method, which is 57.

[11] describe the influence of the Teams Games Tournament (TGT) cooperative learning model and motivation on physics learning outcomes. This research is quasi-experimental research with the factorial design was carried out at SMAN 2 Makassar. There are several findings from this study. Physics learning outcomes students who are taught using the TGT cooperative learning model are higher than students are taught using conventional learning models. There is a significant interaction effect between learning and motivation models for student physics learning outcomes.

[12] researched the effect of applying the Cooperative-Game-Tournament Team(TGT) on understanding and communication in mathematics. The results show that there are significant interactions between group types (group experience \& control) and time period. TGT was found to have an effect on student understanding and communication in mathematics. Cooperative TGT has encouraged students and teachers to be innovative and creative in the process of teaching and learning mathematics in the classroom.

The advantages of this study are compared to the above studies, namely the results of research in the form of improving student performance through the application of the Team Games Tournament (TGT) method in reading Javanese lettered texts. This can be an alternative method for SMA / SMK teachers in teaching Javanese lettered text material so that students are more attractive and interactive in learning Javanese.

\section{CONCLUSIONS}

The results of the discussion above show that the use of the Team Games Tournament (TGT) method can improve the quality of the learning process in terms of student performance and teacher performance. Improving student performance can be proven by increasing the percentage of indicators which include: (1) active students ask; (2) students answer questions 
from the teacher; (3) students take notes without being instructed ; (4) students who attend learning in an orderly manner; and (5) students are not sleepy during learning.

Therefore, the authors suggest: (1) students should be more active and enthusiastic in following Javanese language learning, especially material reading Javanese lettered texts; (2) teachers should improve their competence and creativity in classroom management both in terms of methods and learning media that are in accordance with the subject matter so that it attracts students to take part in learning; (3) teachers should always include students actively in the learning process so that students have direct learning experiences that impact on the ease of understanding learning material; and (4) the school should facilitate complete facilities and infrastructure for learning activities, especially Javanese language learning.

\section{REFERENCES}

[1] Saddhono K 2012 Kajian Sosiolingustik Pemakaian Bahasa Mahasiswa Asing dalam Pembelajaran Bahasa Indonesia untuk Penutur Asing (BIPA) di Universitas Sebelas Maret. Kajian Linguistik dan Sastra, 24 2, Desember 2012 pp 176-186

[2] Saddhono K 2018 Cultural and Social Change of Foreign Students in Indonesia: The Influence of Javanese Culture in Teaching Indonesian to Speakers of Other Languages (TISOL). IOP Conf. Series: Earth and Environmental Science 126 (2018) 012091

[3] Uno H B 2008 Perencanaan Pembelajaran (Jakarta: Bumi Aksara)

[4] Mawardi 2017 Merancang Model dan Media Pembelajaran. Scholaria: Jurnal Pendidikan dan Kebudayaan. 81 pp 26-40

[5] Fu X 2013 An Action Research Report on Applying Co-operative Learning Techniques in an Intensive English Reading Class in China. English Language Teaching 610

[6] Salam A Hossain A and Rahman S 2015 Team Games Tournament (TGT) Cooperative Technique for Learning Mathematics in Secondary School in Bangladesh. Journal of Research in Mathematics Education 43 pp 271-287

[7] Prihatnani E 2016 Prestasi Belajar Matematika Siswa SMA Negeri Kabupaten Kulon Progo dalam Pembelajaran Menggunakan Model TGT Berbantuan Alat Peraga Ditinjau dari Kecerdasan Spasial. Scholaria: Jurnal Pendidikan dan Kebudayaan 62 pp 29-45

[8] Widayanti E R and Slameto 2016 Pengaruh Penerapan Metode Team Games Tournament Berbantuan Permainan Dadu terhadap Hasil Belajar IPA. Scholaria: Jurnal Pendidikan dan Kebudayaan 63 pp 182-195

[9] Hamalik O 1992 Psikologi Belajar dan Mengajar (Bandung: Sinar Baru)

[10] Juliantari N K Sudarsana I K Sutriyanti N K Astawa I N T Putri I D H P and Saddhono $\mathrm{K}$ Educational Games Based in Information Technology as Innovation Evaluation Activity in Learning IOP Conf. Series: Journal of Physics: Conf. Series 1114 (2018) 012041

[11] Nadrah Tolla I Ali M S and Muris 2017 The Effect of Cooperative Learning Model of Teams Games Tournament (TGT) and Students' Motivation toward Physics Learning Outcome. International Education Studies 102 pp 123-130

[12] Veloo A Md-Ali R. and Chairany S 2016 Using Cooperative Teams-Game-Tournament in 11 Religious School to Improve Mathematics Understanding and Communication. Malaysian Journal of Learning and Instruction 132 pp 97-123 